\title{
GEOMETRICAL EFFECTS OF THE ATOMIZER SPIN CHAMBER AND AIR SWIRLER ON FLAME CHARACTERISTICS
}

\author{
Aly Kamel Abd El-Samed \\ Mechanical Power Engineering. Department, Faculty of Engineering, \\ Suez Canal University, Port-Said, Egypt
}

\begin{abstract}
Both of the fuel and combustion air streams were co-swirled to create a strong and stable flame. The effects of changing the geometry of atomizer spin chamber and combustion air swirler on flame characteristics were experimentally investigated. The diameter and depth of the spin chamber also the hub diameter and vanes angle of the combustion air swirler were changed in turn. The experimental runs were carried out within a horizontal water-cooled combustor tube of $32 \mathrm{~cm}$ diameter and $150 \mathrm{~cm}$ length. Kerosene spray was issued at $12.5 \mathrm{bar}$ with constant flow rate of 12.6 $\mathrm{kg} / \mathrm{hr}$ keeping the air/fuel ratio constant at 19 .

Gas temperature distributions, sectional average gas temperatures along the combustor, flame stability limits and overall heat transfer to the combustor wall were determined for the different operating runs.

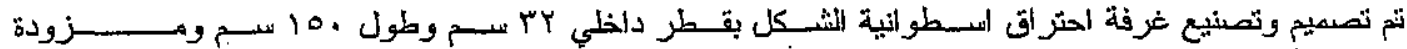

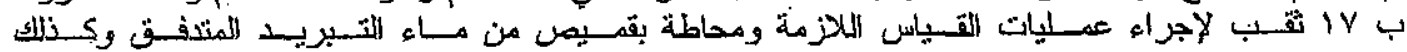

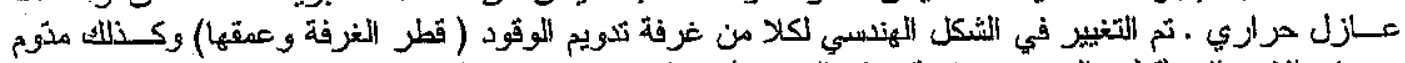

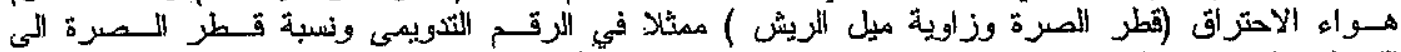

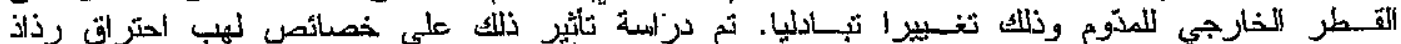

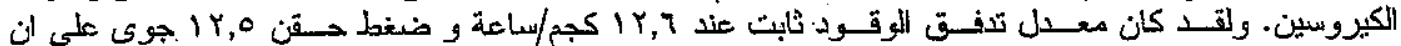

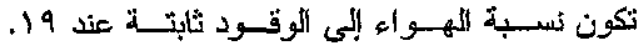

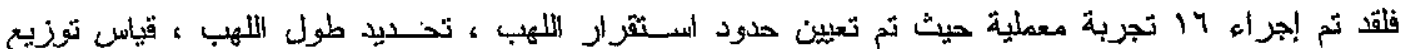

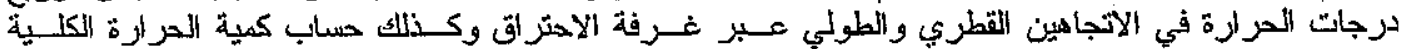

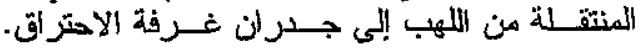

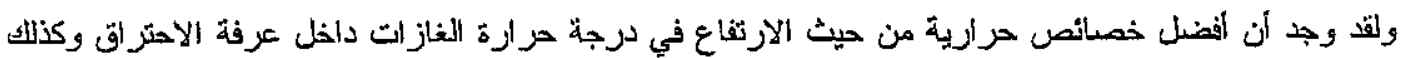

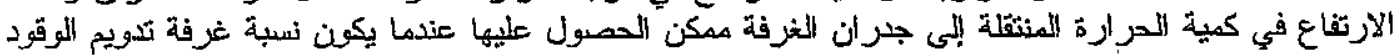

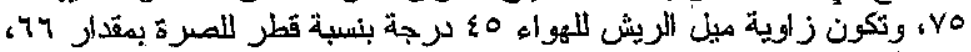

Keywords: Fuel Spin Chamber, Air Swirl Number, Hub diameter ratio, Spray Combustion.

\section{INTRODUCTION}

Fuel and air mixing process plays an important role in combustor performance. The combustion of liquid fuel sprays is of considerable importance to the operation of a wide range of practical combustion systems such as industrial furnaces and boilers, gas turbines and other liquid fired power systems. The interaction of complex physical and chemical processes in the combustion of fuel sprays were discussed [1-4]. The effect of imparting swirl to the surrounding air stream for various combustion systems were reported in several earlier investigations [5-6]. The effect of droplet size and spatial distribution on flame structure, gas flow pattern, temperature, and species measurements were reported [7-14]. The momentum of air and the fuel streams have a great effect on the flow pattern $[6,16]$ and dynamic combustor behavior [15], mixing rate [17] flame stability [18\&19] and combustion intensity [20-22]. Effects of swirler size, dual-coaxial swirlers and swirler rotation on spray combustion were studied [24\&25]. An experimental investigation was carried out to study the effects of fuel nozzle displacement on the structure of a spray [26]. The blowout process and mechanism of diffusion flames were investigated also [27-29].

This work was carried out to investigate the effects of changing the geometry of the atomizer spin chamber and combustion air swirler on the thermal flame characteristics. The atomizer spin chamber parameters which changed were:

1- The diameter of the spin chamber;

2- The depth of the spin chamber.

And the combustion air swirler parameters which changed were:

1- The hub diameter of the air swirler. 
2- The air swirler vanes angle (i.e. swirl number, $\mathrm{SN})$;

Each one of these four parameters was changed in turn, keeping the other three parameters constant. Gas temperature distributions, overall heat transfer to the combustor wall, Lean blowout and stability limits and confined visual flame lengths were investigated.

\section{EXPERIMENTAL ARRANGEMENT}

Schematic diagram of the experimental apparatus is shown in Fig.1. It is mainly composed of; a water cooled combustor, a fuel system and a combustion air system.

The combustor (10) is a horizontal tube with $32 \mathrm{~cm}$ inner diameter and $150 \mathrm{~cm}$ length. It is equipped with 17 tapping holes of $16 \mathrm{~mm}$ diameter arranged in line along the combustor wall. The first seven holes $5 \mathrm{~cm}$ apart but the other ten holes are $10 \mathrm{crn}$ apart. Through these holes, the measuring probes are introduced. The combustor tube is surrounded by cooling-water jacket (15) and covered with a thermal insulation (16).

The fuel system consists of a tank (1), a filter, a gear pump (3) driven by $2 K W$ electric motor, a pressure gauge (5) and the pressure swirl atomizer (14). To achieve spray formation, the Kerosene fuel was pressurized inside the atomizer (14) up to a pressure of $12.5 \mathrm{bar}$ and then discharged with constant flow rate of $12.6 \mathrm{~kg} / \mathrm{hr}$ through a narrow orifice (nozzle) of $0.4 \mathrm{~mm}$ diameter and $1.0 \mathrm{~mm}$ length. This nozzle was formed in the atomizer cup as shown in Fig.2.
To obtain finer spray droplets with a swirling motion, a special atomizer spin chamber was designed and installed. The construction design parameters of the spin chambers (group-1, group-2) are shown in Fig.3. Each spin chamber have four grooved passages with constant depth of $1.0 \mathrm{~mm}$ and constant width of 0.5 $\mathrm{mm}$. The four passages are tangent to the inner surface of the spin chamber and perpendicular to each other. These passages create the swirling motion of the fuel inside the spin chamber and impart to the fuel a high angular velocity. It was noticed from the preliminary runs, that both of the inner diameter and the depth of the spin chamber affect strongly the degree of the fuel swirl. Therefore, two groups were formed; group-1 was concerned with the effect of changing the inner diameter of the spin chamber $\left(d_{s}\right)$ which are ranged from 3 to $5,7,9,10.5$ and $12 \mathrm{~mm}$ keeping the spin chamber depth constant at $4 \mathrm{~mm}$. Group-2 was concerned with the effect of changing the spin chamber depth $\left(\mathrm{L}_{\mathrm{s}}\right)$ as 4 to $7,9.3$ and $12 \mathrm{~mm}$ keeping the spin chamber diameter constant at $7 \mathrm{~mm}$.

The combustion air was emerged from a blower (6), driven by $3 K W$ electric motor, with a constant flow rate of $240 \mathrm{~kg} / \mathrm{hr}$. therefore, the air-fuel ratio is kept constant at 19 for all runs. Eight combustion air swirlers (13) were used in the present investigation. The combustion air swirler with vanes angle of $30^{\circ}$ was designed with different hub diameters $\left(d_{b}\right)$ as 34 , $40,46,51,57$ and $62 \mathrm{~mm}$. this design keeps the outer swirler diameter constant at $77 \mathrm{~mm}$ (group-3).

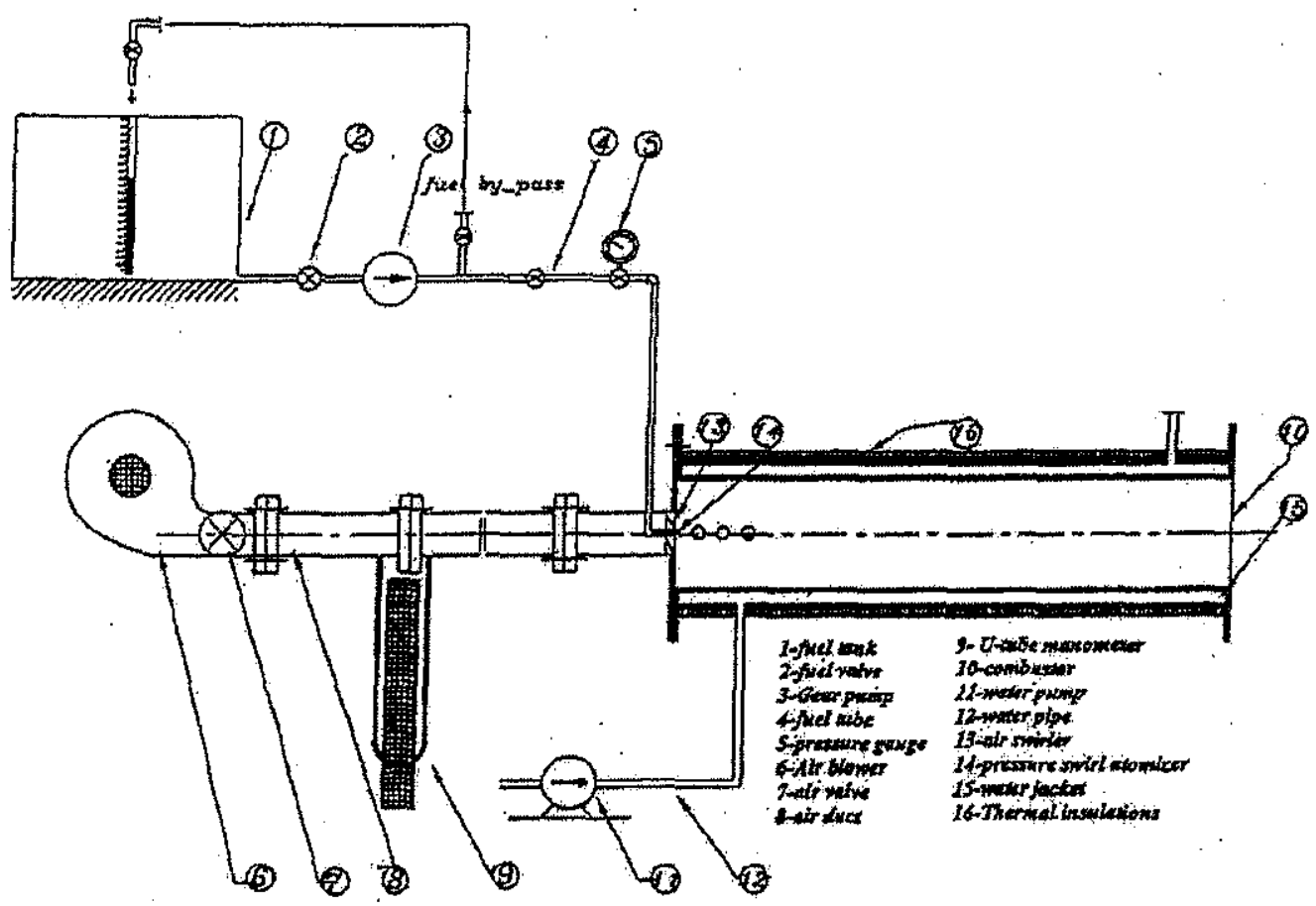

Fig. 1. Schematic diagram of experimental apparatus. 


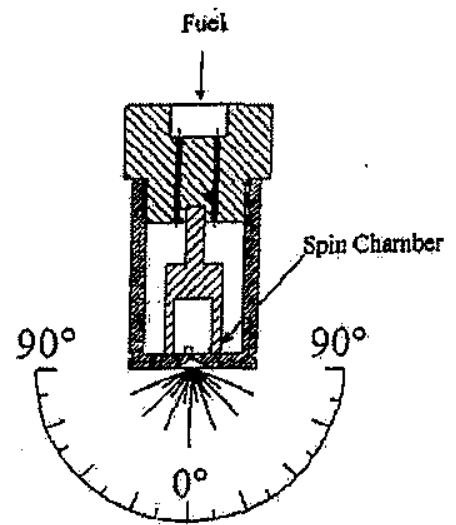

Fig. 2. Sectional diagram of the pressure swirl atomizer.

Spin Chamber

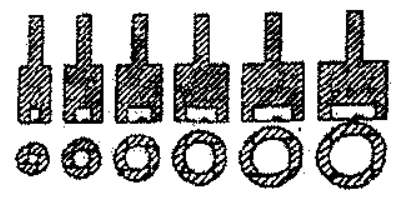

oroup- $1, d_{j}=3,5,7,9,10.5,72 \mathrm{~mm}$

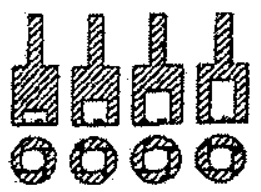

Group $-2, L_{4}=4,7,9,3,12 \mathrm{~mm}$

Fig. 3. Geometrical design parameters.

The corresponding hub diameter ratios (hub diameter/outer diameter) were $0.44,0.52,0.60,0.66$, 0.74 and 0.81 and the corresponding swirl numbers (SN) were $0.44,0.45,0.47,0.49,0.51$ and 0.52 respectively. The air swirl number (SN) was calculated from the following relation [30]:

$\mathrm{SN}=\frac{2}{3}\left(\frac{1-\left(\frac{R_{h}}{R_{\text {out }}}\right)^{3}}{1-\left(\frac{R_{h}}{R_{\text {out }}}\right)^{2}}\right) \tan \alpha$

$R_{h} \quad$ Hub radius of the air swirler,

$R_{\text {out }}$ Outer radius of the air swirler,

A Vanes angle.

For group-4, three combustion air swirlers with vanes angle $30^{\circ}, 45^{\circ}$, and $60^{\circ}$ were considered with constant hub diameter of $34 \mathrm{~mm}$ and outer diameter of $77 \mathrm{~mm}$. The corresponding calculated SN for these swirlers were as $0.44,0.76$ and 1.31 respectively.

Gas temperatures were measured using $100 \mu$ bare wires thermocouples. The wires had a fork-shape with very fine head in the middle of the supporting wires span. The materials of the wires were Pt \& Pt$\mathrm{Rh} 13 \%$. The gas temperatures were measured along a half of the combustor tube -through the 17 holes which drilled along the combustor tube- in the radial direction at incremental distance of $1 \mathrm{~cm}$. Sectional average gas temperature was calculated at every hole level by dividing the cross sectional area of the combustor tube into 16 annular area then applying the following equation;

Sectional average gas temperature $=$

$$
\frac{\sum_{i=1}^{i=16} \bar{t} \times \text { annular area }}{\text { cross sec tional area of the combustor tube }}
$$

$\vec{t}$ average incremental temperatures of the two boundaries of the annular area $_{\mathrm{i}}$.

The lean blow-out limits were determined by setting the combustion airflow rate at a certain level, and a blow out sequence obtained by reducing the fuel rate until the flame extinguished. Ignition is again established and a new airflow rate is selected and blow out is again obtained. This procedure was repeated until a maximum airflow condition was reached.

The flame end was determined visually through the measuring holes and then the flame length was measured using a scaled ruler.

The overall flux of heat transferred to the combustor wall was calculated by measuring the heat gained by the insulated cooling water jacket via measuring the inlet and outlet temperatures for a certain cooling water flow rate using insulated Chromel/Alumel thermocouples.

Overall Heat Flux =

$$
\frac{\bullet}{m_{c . w} \times C_{p c . w} \times \Delta t_{c . w .}}
$$

$\dot{m}_{\text {c.w. }}$ tmass flow rate of the cooling water

$\mathrm{C}_{\mathrm{pcw}}$ specific heat of the cooling water

$\Delta t_{c . w .}$ temperature difference of the cooling water.

The developed spray cone angles were measured directly using a big $180^{\circ}$ angle and $30 \mathrm{~cm}$ in diameter protractor. Two 1000 watt electric flashes were used to focus intensive light on the spray. Values of cone angles were checked and emphasized with the photographs of the spray from two sides of the atomizer using a digital power shot camera -(Canon S10): The shape of the spray distribution was clearly viewed and the spray cone angle was measured. The cone angle is denoted as the angle formed by two straight lines drawn from the discharge orifice to tangent the outermost spray contours at some specified distance from the atomizer face.

The suitable operating conditions for all the experimental test runs such asi atomizing fuel pressure, fuel flow rate, combustion air flow rate and co-swirl streams were chosen after several 
preliminary trials. Run-3 was chosen to be a common case with the all groups. This is because it produces a smoky and unstable flame accompanied the least heat transfer to the combustor wall and also the least gas temperature distributions. Therefore, effects of changing the depths of the spin chamber, the air swirler hub diameters ratios and the air swirl numbers on the combustion improvements could be noticeable clearly. The program of the experimental runs is shown in Table-1 as follows:

Table-1 The program of the experimental runs

Group-1, Changing of spin chamber diameter $\left(\mathrm{d}_{\mathrm{s}}\right)$

\begin{tabular}{|c|c|c||c|c|c|c|}
\hline & \multicolumn{2}{|c|}{ Fuel Spin Chamber } & \multicolumn{4}{c|}{ Combustion Air Swirler } \\
\cline { 2 - 7 } Run No. & $\begin{array}{c}\text { Diameter } \\
\text { of the spin } \\
\text { chamber, }\left(\mathrm{d}_{s}\right) \\
\text { man }\end{array}$ & $\begin{array}{c}\text { Depth } \\
\text { of the spin } \\
\text { chamber, } \\
\left(\mathrm{L}_{\text {s }}\right)\end{array}$ & $\begin{array}{c}\text { Angle } \\
\text { of air } \\
\text { swirler } \\
\alpha\end{array}$ & $\begin{array}{c}\text { Air } \\
\text { Swirl } \\
\text { Number } \\
(\text { SN) }\end{array}$ & $\begin{array}{c}\text { Hub } \\
\text { diameter } \\
\left(d_{11}\right), \text { mm }\end{array}$ & $\begin{array}{c}\text { Hub } \\
\text { diameter } \\
\text { ratio of air } \\
\text { swirler }\end{array}$ \\
\hline Run-1 & $(3)$ & 4 & $30^{\circ}$ & 0.44 & 34 & 0.44 \\
\hline Run-2 & $(5)$ & 4 & $30^{\circ}$ & 0.44 & 34 & 0.44 \\
\hline Run-3 & $(7)$ & 4 & $30^{\circ}$ & 0.44 & 34 & 0.44 \\
\hline Run-4 & $(9)$ & 4 & $30^{\circ}$ & 0.44 & 34 & 0.44 \\
\hline Run-5 & $(10.5)$ & 4 & $30^{\circ}$ & 0.44 & 34 & 0.44 \\
\hline Run-6 & $(12)$ & 4 & $30^{\circ}$ & 0.44 & 34 & 0.44 \\
\hline
\end{tabular}

Group 2, Changing of spin chamber depth (Ls)

\begin{tabular}{|c|c|c|c|c|c|c|}
\hline Run-3 & 7 & $(4)$ & $30^{\circ}$ & 0.44 & 34 & 0.44 \\
\hline Run-7 & 7 & $(7)$ & $30^{\circ}$ & 0.44 & 34 & 0.44 \\
\hline Run-8 & 7 & $(9.3)$ & $30^{\circ}$ & 0.44 & 34 & 0.44 \\
\hline Ruu-9 & 7 & $(12)$ & $30^{\circ}$ & 0.44 & 34 & 0.44 \\
\hline
\end{tabular}

Group-3, Changing of air swirler hub diameter (dh)

(hub diameter ratio $=$ hub diameter/outer diameter)

\begin{tabular}{|c|c|c|c|c|c|c|}
\hline Run-3 & 7 & 4 & $30^{\circ}$ & 0.44 & 34 & $(0.44)$ \\
\hline Run-10 & 7 & 4 & $30^{\circ}$ & 0.45 & 34 & $(0.52)$ \\
\hline Run-11 & 7 & 4 & $30^{\circ}$ & 0.47 & 34 & $(0.60)$ \\
\hline Run-12 & 7 & 4 & $30^{\circ}$ & 0.49 & 34 & $(0.66)$ \\
\hline Run-13 & 7 & 4 & $30^{\circ}$ & 0.51 & 34 & $(0.74)$ \\
\hline Run-14 & 7 & 4 & $30^{\circ}$ & 0.52 & 34 & $(0.81)$ \\
\hline
\end{tabular}

Group-4, Changing of air swirl angle, $\alpha$ (i.e. swirl number)

\begin{tabular}{|c|c|c|c|c|c|c|}
\hline Run-3 & 7 & 4 & $\left(30^{\circ}\right)$ & 0.44 & 34 & 0.44 \\
\hline Run-15 & 7 & 4 & $\left(45^{\circ}\right)$ & 0.76 & 34 & 0.44 \\
\hline Run-16 & 7 & 4 & $\left(60^{\circ}\right)$ & 1.31 & 34 & 0.44 \\
\hline
\end{tabular}

\section{RESULTS AND DISCUSSIONS}

As the atomizer fuel pressure was increased gradually, it was began to discharge from the atomizer nozzle in the form of a solid jet then it was twisted and formed cork-screw with insufficient swirl velocity to produce an air core. As the injection pressure was increased the jet began to break up and the developed hollow-cone spray was formed. These stages were visualized clearly with the help of 1000 watt flashes. Similar results were obtained $[31,32]$.

Using air swirler which creates vortex motions inside the combustor, a central recirculation zone was formed. This increases turbulence and mixing rate of fuel and air streams. When combustion was occurred, the reversed hot combustion products heat-up the fresh mixture and stable flame was formed and high chemical reaction rate zone was recorded upstream referring to the highest gas temperatures in that zone. The radial gas temperature was reduced as moving towards the combustor wall.

Flame stability is described in terms of blow-out and stable flame. The blow-out means stop flame burning by blowing air at the flame. Stable flame means the flame properties are continuously steady. The two conditions, which are the blowout and the stable flames limits for the 16 runs are displayed in Fig.4. These curves are found to be close to each other and all of them have the same trend. As the fuel flow rate 
increased from 0.36 to $0.5 \mathrm{~kg} / \mathrm{hr}$, the required air flow rate increased sharply from 72 to $162 \mathrm{~kg} / \mathrm{hr}$ and the corresponding Air/fuel ratios were 200 and 324 respectively. Further increase in the fuel flow rate, the air flow rate (i.e. the slope of the curve) increases very slightly until the air/fuel ratio reduced to 87 at fuel flow rate $2.15 \mathrm{~kg} / \mathrm{hr}$. These values of the air/fuel ratio are exceeded the limits of many practical combustion applications. That means the designed atomizer produces more stable flames for a wide range of different operating conditions.

The local gas temperatures were measured in both radial and axial directions at 289 points along the half of the combustor tube. Then maps (contours) and sectional average gas temperatures were drawn for all the runs of the different operating conditions assuming axi-symmetric measurements along the combustor. The maximum recorded gas temperature value of $1280^{\circ} \mathrm{C}$ was found corresponding to Run-2, at dimensionless axial distance $\mathrm{x} / \mathrm{L}=0.08-0.12$ and at dimensionless radial distance $\mathrm{r} / \mathrm{R}=0.6-0.8$. It seems that the maximum temperature (i.e the maximum reaction rate) can be attributed to the effect of bigh evaporation and mixing rates, where the suitable spray cone angle was found to be $75^{\circ}$.

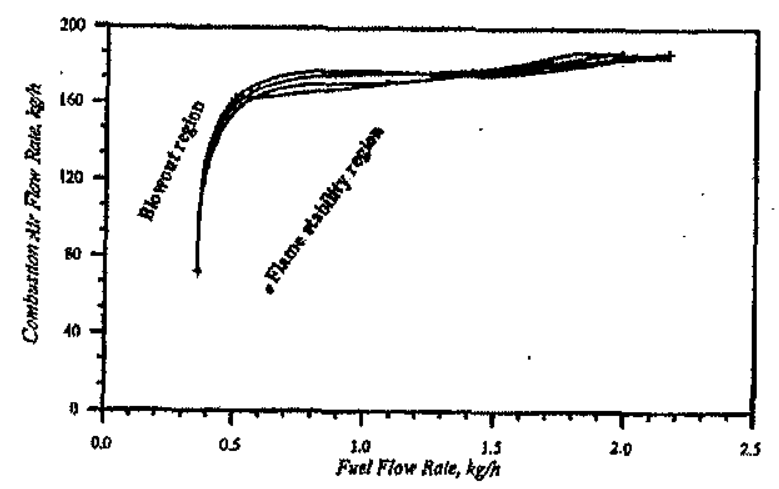

Fig. 4. Lean blowout and flame stability limits (16 Runs).

\subsection{Effect of Changing the Spin Chamber Diameter $\left(d_{s}\right)$, (i.e.Group-1)}

As the spin chamber diameter increased from 3 to 5 , $7,9,10.5$, and $12 \mathrm{~mm}$ keeping the depth of the spin chamber constant at $4 \mathrm{~mm}$; the corresponding produced spray cone angles were $98^{\circ}, 75^{\circ}, 36^{\circ}, 62^{\circ}$, $66^{\circ}$, and $75^{\circ}$ respectively. These cone angles were measured by the protractor and emphasized from the photographs of the spray cone angles which shown in Fig.5a and presented in Fig.5b. The widest fuel spray cone angle of this group was $98^{\circ}$ corresponding to spin chamber diameter $3 \mathrm{~mm}$ (Run-1). Therefore fuel spray had more opportunity for faster evaporation rate and consequently faster mixing rate with the combustion air as a result, the shortest flame length of $55 \mathrm{~cm}$ was obtained. While the maximum flame length of $150 \mathrm{~cm}$ corresponds to diameter $7 \mathrm{~mm}$, i.e. Run-3.

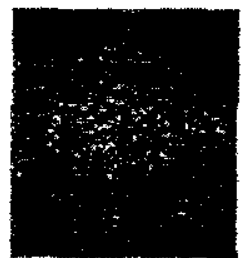

Rum $1\left(98^{\circ}\right)$

Diameter $=3 \mathrm{~mm}$

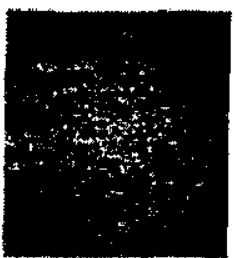

Run $4\left(62^{\circ}\right)$

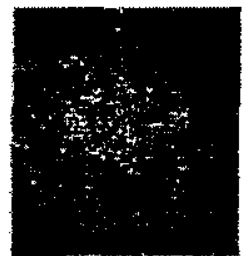

Rin $2\left(75^{\circ}\right)$ Diameter $=5 \mathrm{~mm}$

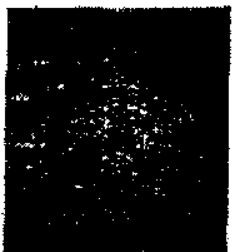

Run $5\left(66^{\circ}\right)$

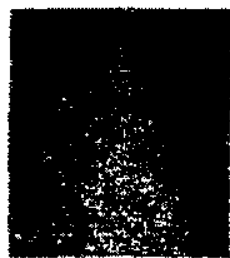

$\operatorname{Run} 3\left(36^{\circ}\right)$ Diameter $=7 \mathrm{~mm}$

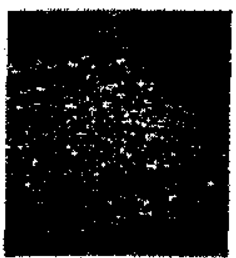

$\operatorname{Run} 6\left(75^{\circ}\right)$
Diameter $=9 \mathrm{~mm}$ Diameter $=10.5 \mathrm{~mm}$ Diameter $=12 \mathrm{~mm}$

Fig. 5a. Photographs Emphasize the effect of fuel spin chamber diameter on the values of the measured spray cone angles.

(with constant spin chamber depth $=4 \cdot \mathrm{mm}$ )

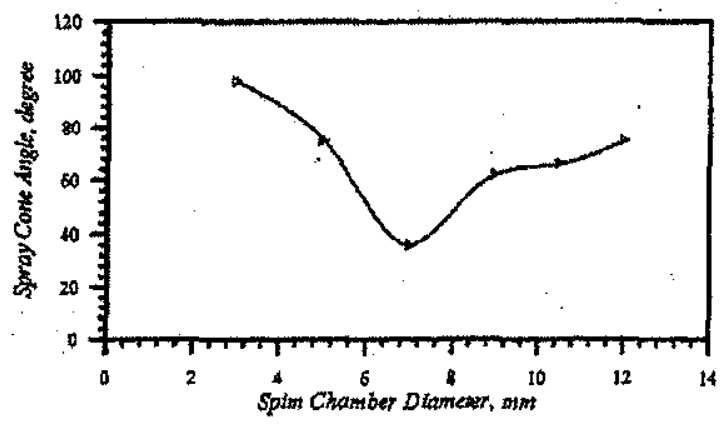

Fig. 5b. Effect of fuel spin chamber diameter on the values of the measured spray cone angles.

The confined flame length was found to be changed remarkably with the change of the spin chamber diameter as presented in Fig.6. The obtainable confined flames of these runs, in general, were stable with golden colour except the flame of Run-3, with spin chamber diameter of $7 \mathrm{~mm}$, which accompanied with a lot of soot.

Gas temperature distributions were influenced too much with the change of the spin chamber diameter as shown from the gas temperatures contours in Fig.7. For spin chamber diameter $3 \mathrm{~mm}$ (Run-1) it can be noticed that the high reaction rate zone (i.e. the highest gas temperature zone) was found around the axis of the combustor at $r / R=0.2-0.95$, and $x / L=$ $0.033-0.4$, in other words it extended in a large volume beginning very close to the atomizer exit and extended to the middle of the combustor. As the spin chamber diameter increased from 3 to 5 and $7 \mathrm{~mm}$ the high reaction rate zone shrink and occupied a smaller volume and moved inward toward the 
combustor axis closer to the atomizer exit. Consequently, the sectional average gas temperature along the combustor decreased and its value at the combustor exit was $750^{\circ} \mathrm{C}, 600^{\circ} \mathrm{C}$ and $580^{\circ} \mathrm{C}$ respectively as shown in Fig.8. More increases in the spin chamber diameter to $9,10.5$ and $12 \mathrm{~mm}$ causes a displacement of the high reaction rate zone outward toward the combustor wall. Consequently, the sectional average gas temperature at combustor exit increases and then decreases as $740^{\circ} \mathrm{C}, 705^{\circ} \mathrm{C}$, and $665^{\circ} \mathrm{C}$ respectively. It was noticed from the figure that the general trend of the sectional average gas temperature along the combustor was increased gradually up to higher reaction rate zones upstream and then decayed smoothly downstream where the reaction ended.
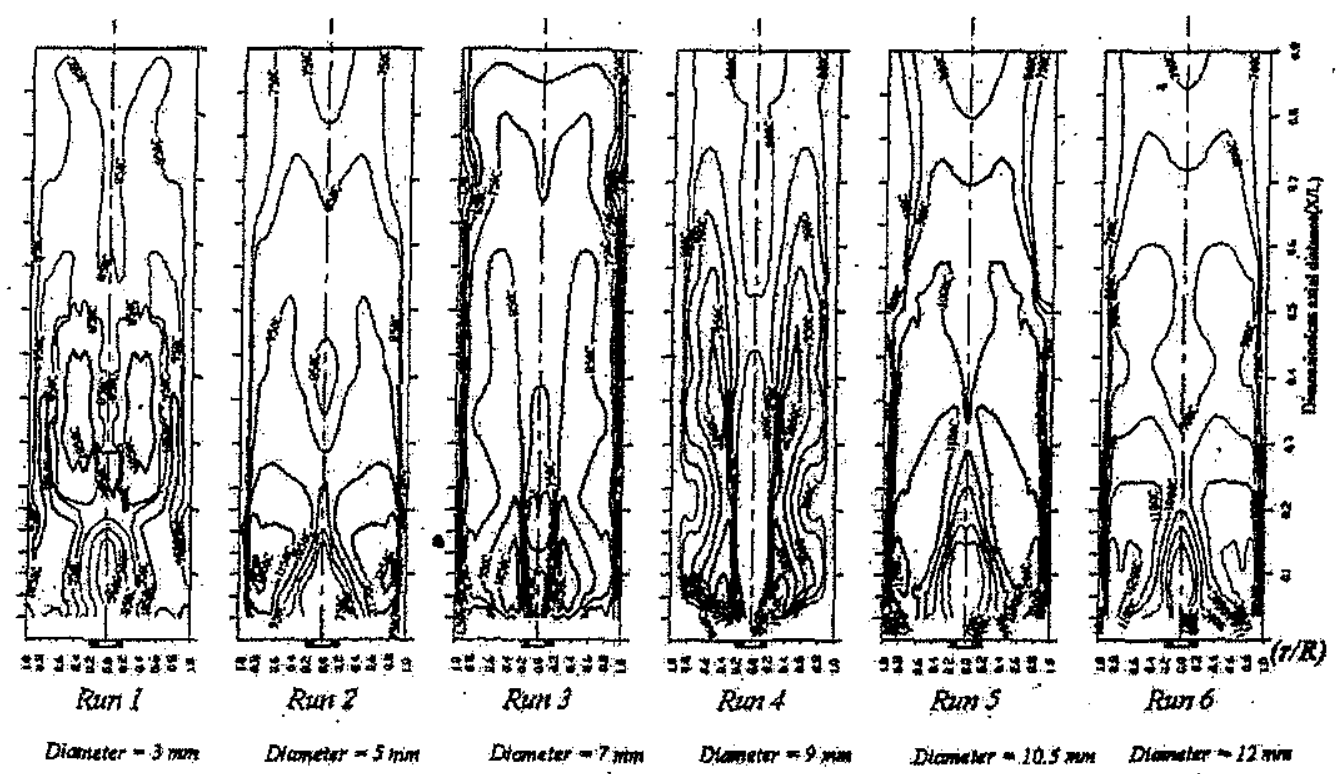

Fig. 7. Effect of spin chamber diameter on gas temperature contours along the combustor. (with constant spin chamber depth $=4 \mathrm{~mm}$ )

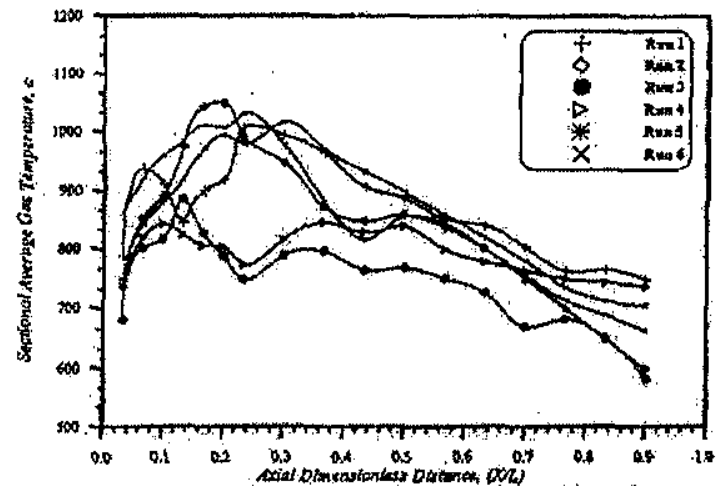

Fíg. 8. Effect of spin chamber diameter on the sectional average gas temperature along the combustor.

As a result, the maximum heat flux value of 57.2 $\mathrm{Kj} / \mathrm{m}^{2} . \mathrm{s}$ was found to be for spin chamber diameter 3 mm (Run-1), with spin chamber ratio (spin diameter $(3 \mathrm{~mm}) / \mathrm{spin} \operatorname{depth}(4 \mathrm{~mm}))=0.75$ while the minimum value of $53.72 \mathrm{Kj} / \mathrm{m}^{2} . \mathrm{s}$ corresponds to spin chamber diameter $7 \mathrm{~mm}$, (Run-3) as presented in Fig.9.

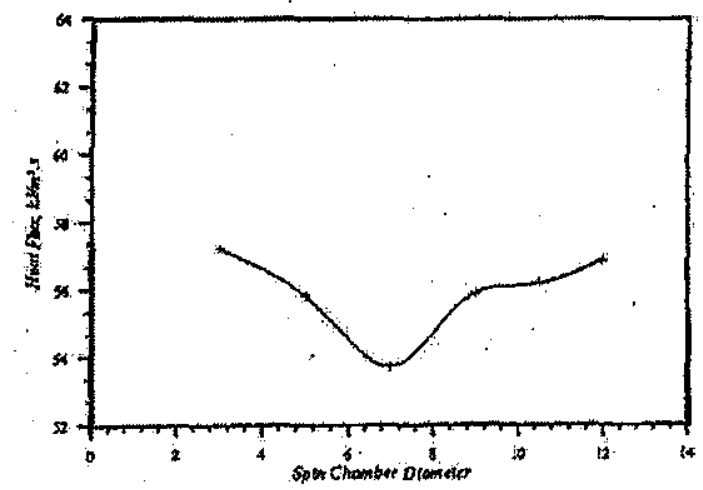

Fig. 9. Effect of spin chamber diameter on overall heat transfer to the combustor wall. 


\subsection{Effect of Changing the Spin Chamber Depth} $\left(L_{\mathrm{s}}\right)$, (i.e. Group-2)

As the depth of the fuel spin chamber was changed from 4 to $7,9.3$ and $12 \mathrm{~mm}$, keeping the chamber diameter constant at $7 \mathrm{~mm}$, the measured spray cone angles which corresponding to these depths were found to be $36^{\circ}, 64^{\circ}, 76^{\circ}$ and $54^{\circ}$ respectively as shown from Fig. 10a and presented in Fig.10b.

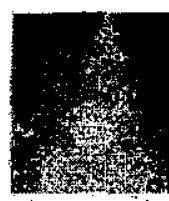

Run $3\left(36^{\circ}\right)$ Depth $=4 \mathrm{~mm}$

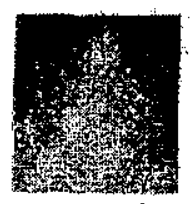

$\operatorname{Rim} 7\left(64^{\circ}\right)$ Depth $=7$ mino

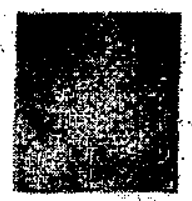

$\operatorname{Ran} 8(76 \%)$ Degth $=9.3 \mathrm{~min}$

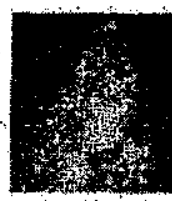

Risin $9\left(54^{\circ}\right)$ (⿻)丨
Fig. 10a. Photographs emphasize the effect of fuel spin chamber depth on the values of the measured spray cone angles (with constant spin chamber diameter $=7 \mathrm{~mm}$ )

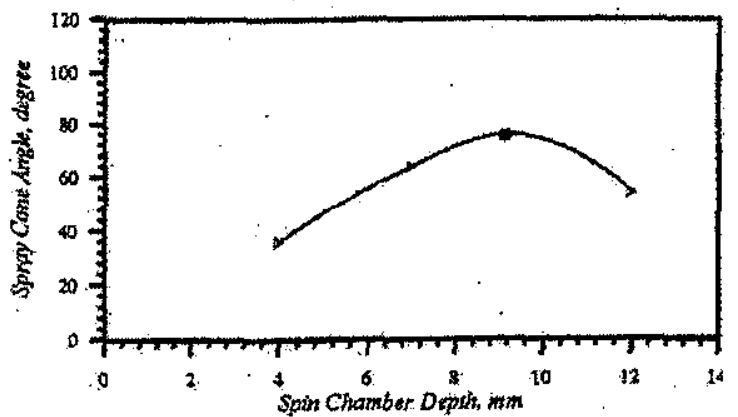

Fig. 10b. Effect of fuel spin chamber depth on the values of the measured spray cone angles.

The trend of the flame length was found to be the same trend of the value of the spray cone angle as
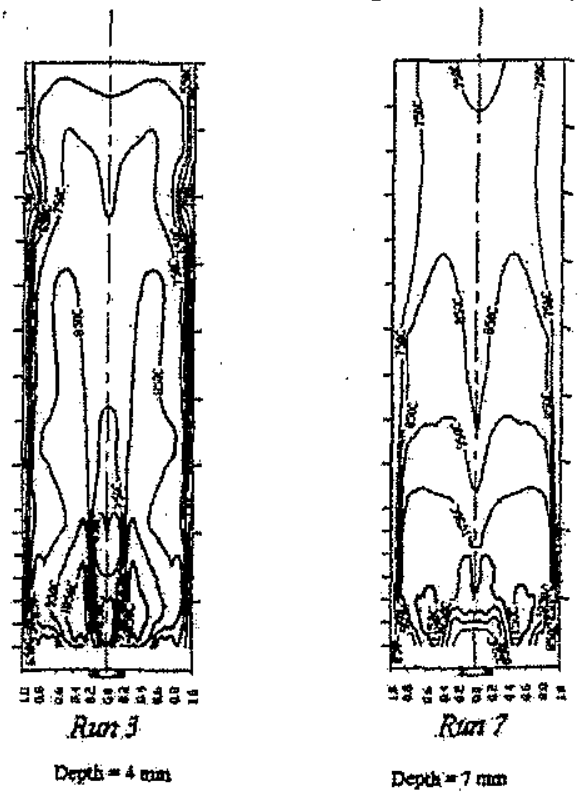

shown from Fig.11. The largest cone angle and consequently the highest fuel evaporation rate was found for spin chamber depth $9.3 \mathrm{~mm}$, Run-8, and the obtained flame was wrinkled, golden colour, wide and covers most the radial-upstream section of the combustor. More increase in chamber depth leads to a poor quality of combustion. That the flame for 12 $m m$ depth, Run-9, was orange black color accompanied with soot at exhaust section and it was smooth in shape, long, narrow and the flame it self convoluted in the form of a flying cylinder around the combustor axis.

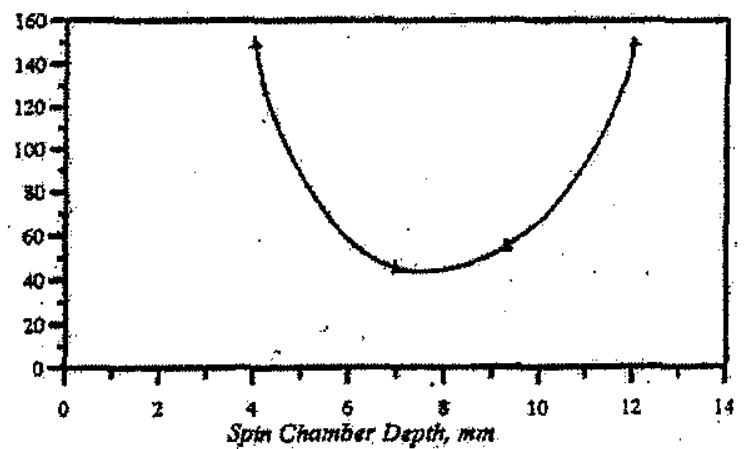

Fig. 11. Effect of spin chamber depth on confined flame length.

As the spin chamber depth was increased from 4 to 7 and $9.3 \mathrm{~mm}$, the highest gas temperatures zone which referred to as the highest reaction rate zone was displaced away from the combustor axis and moves towards the combustor wall. Further increase in the depth up to $12 \mathrm{~mm}$, the high reaction rate zone was returned back to its place around the combustor axis and closer to the atomizer exit as shown from Fig. 12.

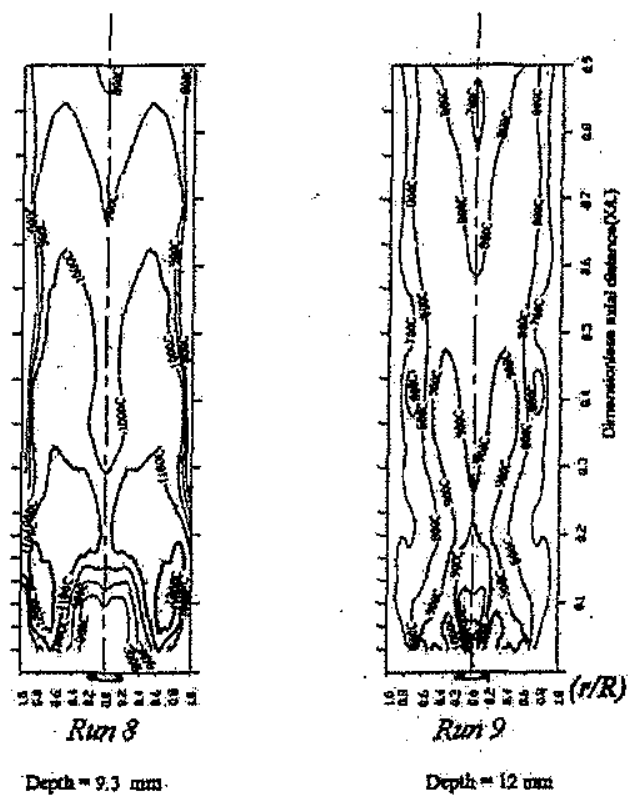

Fig. 12. Effect of spin chamber depth on gas temperature contours along the combustor. (with constant spin chamber diameter $=7 \mathrm{~mm}$ ) 
The highest gas temperature of $1272^{\circ} \mathrm{C}$ was recorded for spin chamber depth $9.3 \mathrm{~mm}$, Run -8 , at $\mathrm{r} / \mathrm{R}=0.75$ and $\mathrm{x} / \mathrm{L}=0.133$ as shown in Fig.12. Also, the highest sectional average gas temperatures along the combustor were found for spin chamber depth 9.3 $\mathrm{mm}$ as shown in Fig.13, and its peak value was $823^{\circ} \mathrm{C}$.

Changing of the spin chamber depth had a great effect on the heat transfer to the combustor wall. As the depth changed from 4 to $9.3 \mathrm{~mm}$ the near wall gás temperatures were increased as shown in Fig.12. Consequently, the heat flux value was increased from 53.72 to $62.32 \mathrm{Kj}^{2} \mathrm{~m}^{2}$.s which represents the greatest value of heat transfer to the combustor wall. The maximum values of gas temperatures along the combustor are corresponding to spin chamber depth $9.3 \mathrm{~mm}$ (Run-8) with spin chamber ratio (depth (7 $\mathrm{mm}) /$ diameter $(9.3 \mathrm{~mm}))=0.75$. Further increase in the depth reduced the heat flux value to 54.375 $\mathrm{kj} / \mathrm{m}^{2} . \mathrm{s}$, that shown in Fig.14. It can be noticed clearly that the order of the heat transfer to the combustor wall from 53.72 to $53.3,62.32$ and 54.375 $\mathrm{Kj} / \mathrm{m}^{2} . \mathrm{s}$ which corresponding to depths $4,7,9.3$ and $12 \mathrm{~mm}$ respectively is related and coincides with that of the sectional average gas temperature as shown in Fig.13.

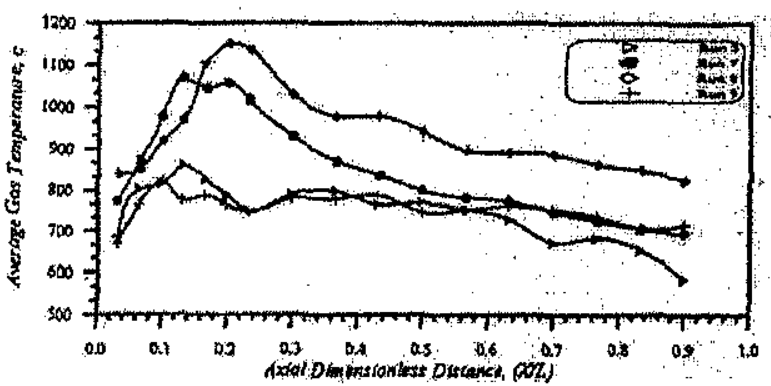

Fig, 13. Effect of spin chamber depth on the sectional average gas temperature along the combustor.

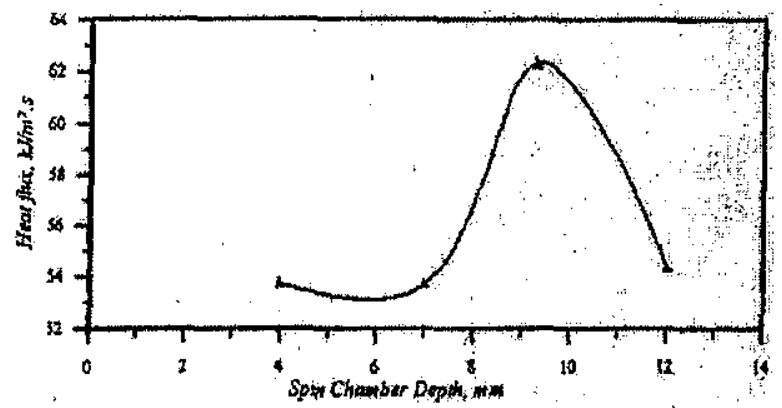

Fig. 14. Effect of spin chamber depth on overall heat transfer to the combustor wall.

\subsection{Effect of Changing the Air Swirler Hub Diameter $\left(d_{h}\right)$, (i.e. Group-3)}

As the air swirler hub diameter $\left(d_{h}\right)$ was increased from 34 to $40,46,51,57$ and $62 \mathrm{~mm}$ the hub diameter ratio (= hub diameter/outer diameter) was increased from 0.44 to $0.52,0.60,0.66,0.74$ and 0.81 the corresponding swirl number (SN) was increased from 0.44 to $0.45,0.47,0.49,0.51$ and 0.52 respectively. The obtained flame length was nearly constant at $150 \mathrm{~cm}$ except for $\mathrm{SN}=0.52$, the flame length was decreased sharply to $85 \mathrm{~cm}$ as shown from Fig.15.

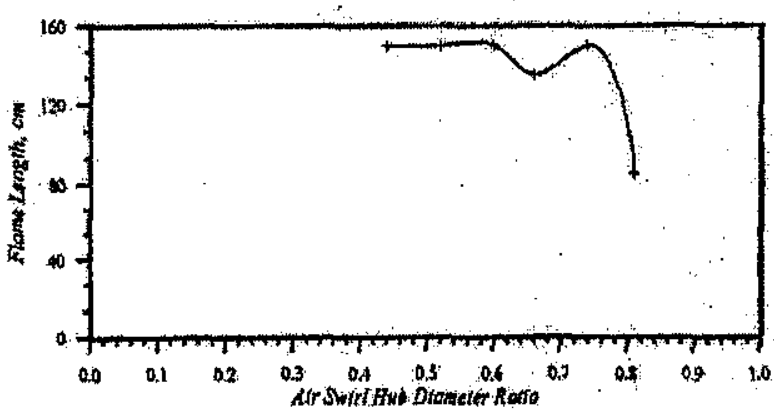

Fig. 15. Effect of air swirler hub diameter ratio on confined flame length.

Up to the hub diameter ratio 0.74 , the bighest reaction rate zone was shifted slightly towards the combustor wall and extending to cover a larger area of the combustor and then it was shrinking at the ratio of 0.81 as shown in Fig. 16. As the hub diameter ratio was increased from 0.44 to 0.52 (i.e. $\mathrm{SN}$ from 0.44 to 0.45 ), it was noticed from Fig.16 that the average gas temperatures along the combustor was increased remarkably by about $150^{\circ} \mathrm{C}$ and the sectional average gas temperatures at exit section was also increased from $584^{\circ} \mathrm{C}$ to $742^{\circ} \mathrm{C}$ as shown in Fig.17. This indicates that, a slight increase of SN from 0.44 to 0.45 had a great effect on gas temperatures values and consequently heat transfer to the combustor wall which was increased from 53.5 to $57.2 \mathrm{Kj} / \mathrm{m}^{2}$.s. But further increase of SN up to 0.52 , leads to a slight fluctuation of the values of gas temperature and heat transfer. So, it is recommended to proceed combustion at swirl number (SN) not less than 0.45 . As the hub diameter ratio increased, the exhaust soot was vanished and the flame colour was changed from orange to golden and heat transfer values to the combustor wall were fluctuated. The maximum heat flux value of $58.76 \mathrm{Kj} / \mathrm{m}^{2} . \mathrm{s}$ was found to be for hub diameter ratio $0.66(\mathrm{SN}=0.49)$ as shown in Fig. 18.

\subsection{Effect of Changing the Air Swirl Angle (a), (i.e. Group-4)}

As the combustion air swirl angle was increased from $30^{\circ}$ (Run-3) to $45^{\circ}$ (Run-15) and $60^{\circ}$ (Run-16) the swirl number (SN) were extremely increased from 0.44 to 0.76 and 1.31 respectively. Consequently, the rotational momentum imparted to the flow was increased leading to a reduction in flame length from 150 to 85 and $75 \mathrm{~cm}$ respectively, as presented in Fig.19. Also, the bigh reaction rate zone was moved towards the combustor wall and displaced 
downstream as shown from Fig.20. As swirl number increased from 0.44 to 0.76 , the sectional average gas temperatures were increased remarkably and the corresponding exit gas temperature was increased from $584^{\circ} \mathrm{C}$ to $830^{\circ} \mathrm{C}$ as shown in Fig.21. Further increase of SN from 0.76 to 1.31 leads to a slight reduction of the sectional average gas temperatures and also the exit gas temperature was decreased from

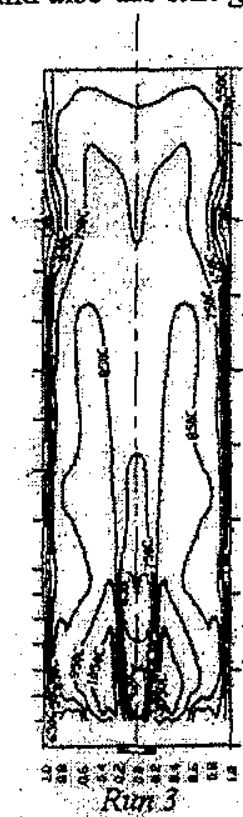

$R a t o=0.44$
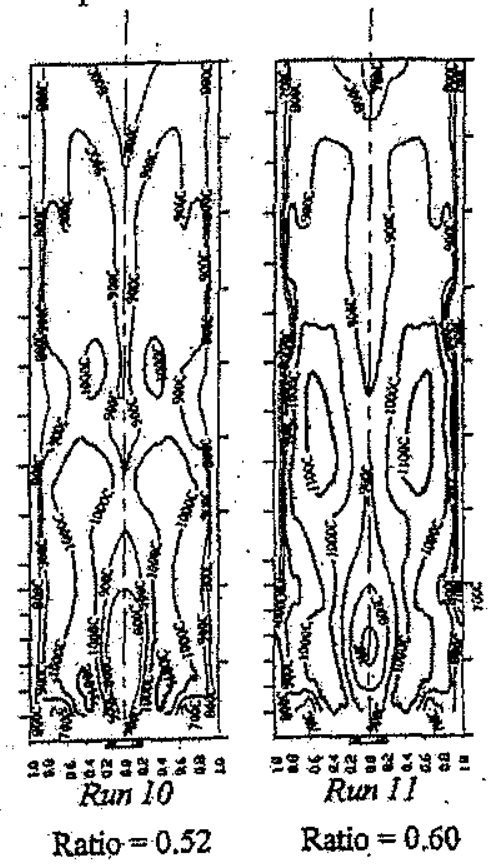

$830^{\circ} \mathrm{C}$ to $813^{\circ} \mathrm{C}$. That reflected on the heat transfer to the combustor wall, where the heat flux was increased and then decreased and their corresponding values were $53.72,57.57$ and $56,945 \mathrm{Kj} / \mathrm{m}^{2} \cdot \mathrm{s}$ respectively, as shown in Fig.22. The highest sectional average gas temperatures and the highest heat transfer flux was found to be for air swirl angle $45^{\circ}(\mathrm{SN}=0.76)$, Run-15.

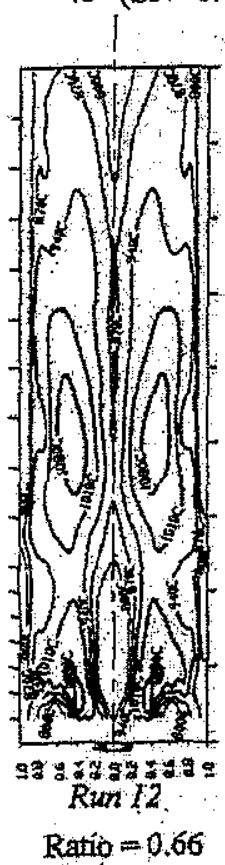

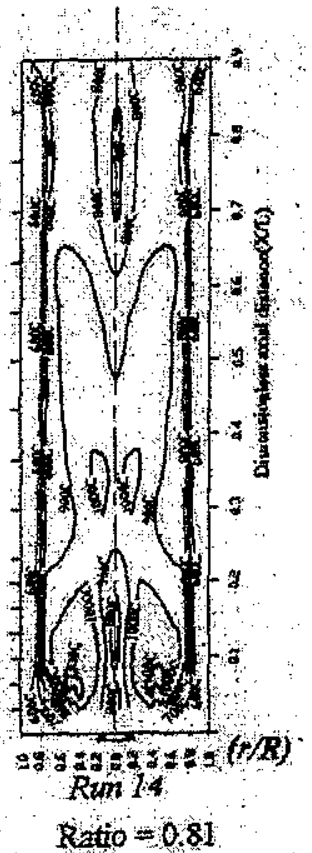

Fig. 16. Effect of air swirler hub diameter ratio on gas temperature contours along the combustor. (with constant spin chamber diameter $=7 \mathrm{~mm} \&$ spin chamber depth $=4 \mathrm{~mm}$ )

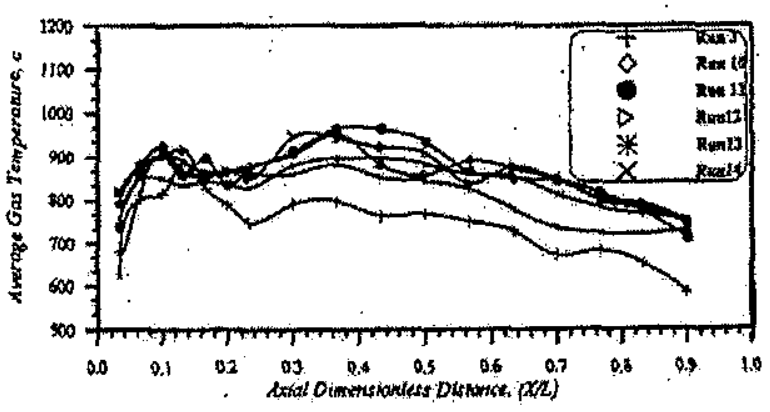

Fig. 17. Effect of air swirler hub diameter on the sectional average gas temperature along the combustor.

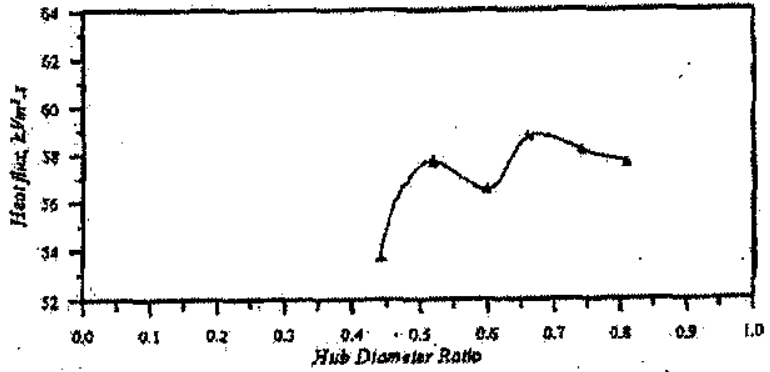

Fig. 18. Effect of air swirler hub diameter ratio on overall heat transfer to the combustor wall.

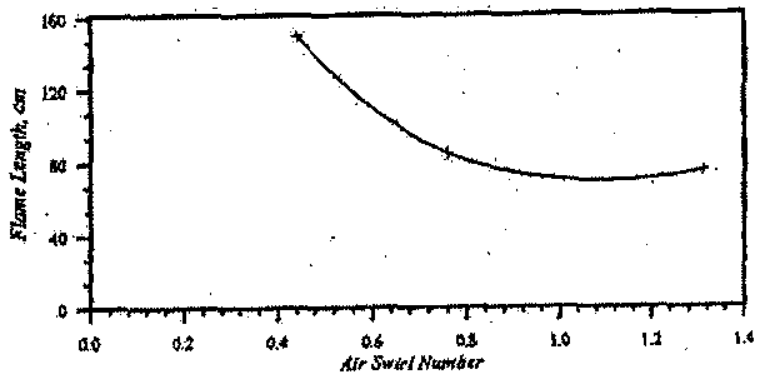

Fig. 19. Effect of air swirl number on confined flame length. 

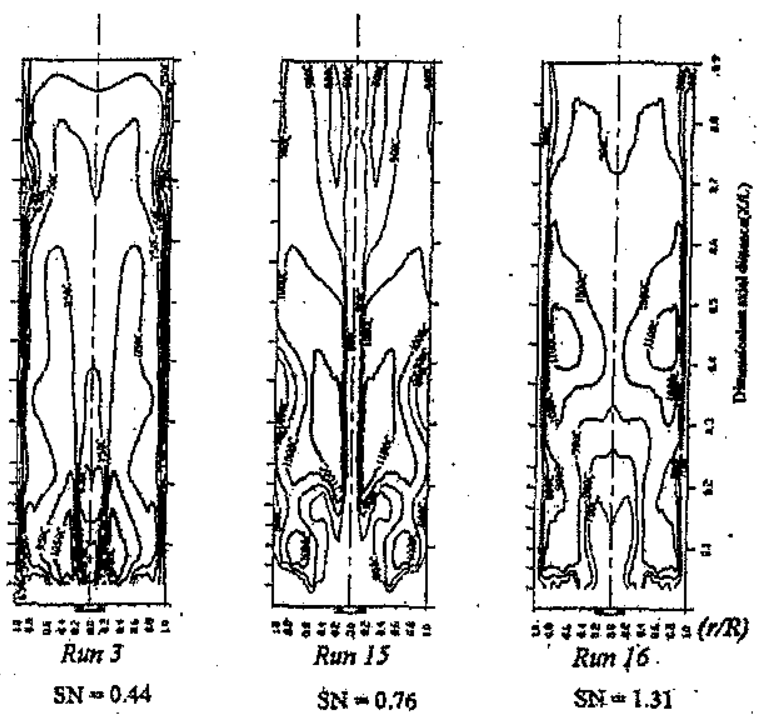

temperature distributions, overall heat transfer to the combustor wall, Lean blowout and flame stability limits, and confined visual flame lengths were determined and the following were concluded:

1. Curves of flames stability limits were obtained for the different operating conditions.

2. Changing the diameter and depth of the atomizer spin chamber and the hub diameter and vanes angle of the combustion air swirler have great effects on: flame length, gas temperature distributions, sectional average gas temperatures along the combustor, and the overall heat transfer to the combustor wall.

3. Better thermal characteristics of Kerosene flames referring to the highest values of gas temperature distributions along the combustor and heat transfer to the combustor wall were obtained at the following conditions:

Fig. 20. Effect of air swirl number on gas

temperature contours along the combustor.

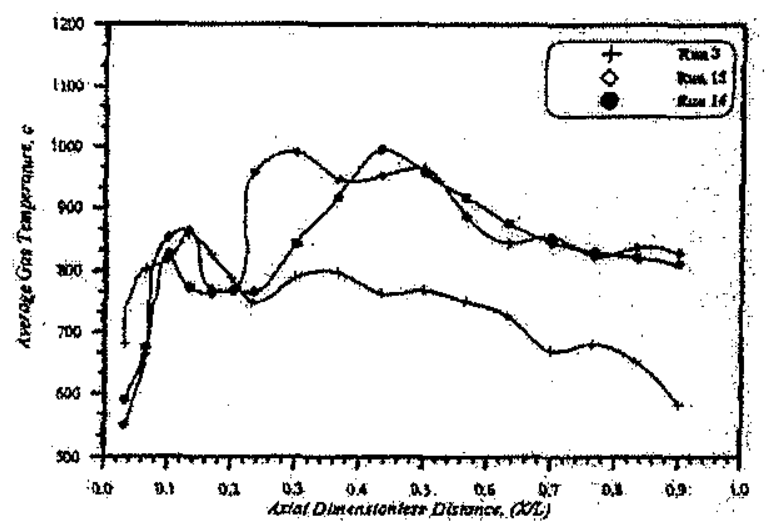

Fig. 21. Effect of air swirl number on the sectional gas temperature along the conbustor.

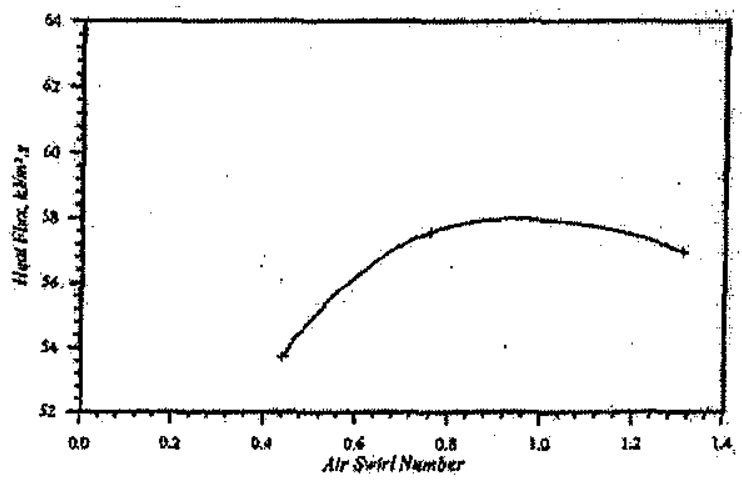

Fig. 22. Effect of air swirl number on the overall heat transfer to the combustor wall.

\section{CONCLUSIONS}

Effect of changing the geometry of the atomizer spin chamber (diameter and depth) and combustion air swirler (vanes angle and hub diameter) on the thermal flame characteristics were investigated. Each one of these four parameters was changed in turn,

a) Spin chamber diameter of $3 \mathrm{~mm}$, i.e. spin chamber ratio of 0.75 , heat flux to the combustor wall is $57.2 \mathrm{Kj} / \mathrm{m}^{2} . s$ (i.e. Run-1).

b) Spin chamber depth of $9.3 \mathrm{~mm}$, i.e. (also) spin chamber ratio of 0.75 , heat flux to the combustor wall is $62.32 \mathrm{Kj} / \mathrm{m}^{2} . s$, (i.e. Run-8).

c) Hub diameter of the combustion air swirler 51 $\mathrm{mm}$, i.e. swirl number of 0.49 and hub diameter ratio of 0.66 , heat flux to the combustor wall is $58.76 \mathrm{Kj} / \mathrm{m}^{2} . \mathrm{s}$, Run- 12 .

d) Vanes angle of the combustion air swirler $45^{\circ}$, i.e. swirl number of 0.76 and hub diameter ratio of 0.44 , heat flux to the combustor wall is $57.57 \mathrm{Kj} / \mathrm{m}^{2} . s$, Run-15.

4. The best thermal flame characteristics could be obtained by combining the following design parameters; the atomizer spin chamber ratio 0.75 (i.e. depth of $9.3 \mathrm{~mm}$ ), equipped with a combustion air swirler with vanes angle $45^{\circ}$ and hub diameter ratio of 0.66 (i.e. hub diameter of 51 $\mathrm{mm}$ ).

\section{REFERANCES}

[1] Faeth, G.M., Progress in Energy and Combustion Science, Vol.9, pp: 1-76 (1983).

[2] Smoot, L.D., and Hill, S.C., Progress in Energy and Combustion Science, Vol.9, pp: 77-103 (1983).

[3] Law, C.K., Progress in Energy and Combustion Science, Vol.8, pp: 169-199 (1982).

[4] William, A.K., Progress in Energy and Combustion Science, Vol.2, pp: 167-179 (1976).

[5] Gupta, A.K., Lilly, D.G., and Syred, N., "Swirl Flow", Abacus press, Kent, (1984).

[6] El-Banhawy, Y., and Whitelaw, J.H., Combustion and Flame, Vol.54, pp: 253-275, (1981). 
[7] Yule, A.J., AhSeeng, C., Felton, P.G., Urget,A., and Chigier, N.A., Combustion and Flame, Vol.44, pp: 71-84, (1982).

[8] Yule, A.J., Ereaut, P.R., and Urget, A., Combustion and Flame, Vol.54, pp: 15-22, (1983).

[9] Komiyama, K., Flagon, R.C., and Heywood, J.B., Sixteenth Symposium Institute, Int., on combustion, the Combustion Institute, Pittsburgh, P.549, (1977).

[10] Onuma, Y., Ogasawara, M., and Inoue, $T$. , Sixteenth Symposium Institute, Int., on combustion, the Combustion Institute, Pittsburgh,pp:561-567,(1977).

[11] Presser, C., Gupta, A.K., and Semerjian, H.G., Combustion and Flame, Vol.92, pp: 25-44, (1993).

[12] Toshimi Takagi, Hyun Dong Shin and Akra Ishio, Combustion and Flame, Vol.41, pp: 261271 (1981).

[13] Mercier X.,Therssen E., Pauwels J.F., and Desgroux P., Combustion and Flame, Vol.125, pp: 656-667, (2001).

[14] Nayan Patel and Suresh Menon, Combustion and Flame, Vol.153, issue 2, pp: 228-257, April (2008).

[15] D.M.Kang, F.E.C.Culick, and A.Ratner, Combustion and Flame, Vol.151, issue 3, pp: 412-425, November (2007).

[16] McCreath, P.T., and Chigier, N.A., Proc. $14^{\text {th }}$ Symp.(Int.) on Combustion, pp:1353-1363, (1973).

[17] Presser, C., Goldman, Y., Greeberg, J.B., and Timnat, Y.M., Proc. $18^{\text {th }}$ (Int.) Symp. On Combustion, pp:1939-1948, (1981).

[18] Chigier, N.A., Combustion Science and technology, vol.3, No.1,pp:31-37, (1965).

[19] Moneib, H.A., Ismail, M.A., and Hussien, A.M.M., Proceeding of $7^{\mathrm{Th}}$. Int.Conf. of Mech.Power Eng.,Vol. 1,II-18, Cairo, December, pp: 17-20, (1990).

[20] Owen, F.K., Spadaccini, I.J., Kennedy, J.B., and Bowman, C.T., Proc. $17^{\text {th }}$ Symp. (Int.) on Combustion (1978).

[21] El-Banhawy, Y.H., El-Ehwany, A.A., and Hagag, E.H., Proc. $7^{\text {th }}$ Conference (Int.) of Mech. Power Eng., Vol.1, pp:II/(21-1)-(21-14), (1990).

[22] El-Mahallawy, F.M., Khalil, E.E., and Abdel-al, O., The Fourth (Int.) Conference for Mech. Power Eng., Cairo, (1982).

[23] Pan, J.C., Schmoll, W.J., and Ballal, D.R., ASME Journal of Engineering for Gas Turbine and Power, Vol.114. pp:33-38, (1992).
[24] Farag, T.M., S.I.,Abdel-Mageed, E-S A., Ibrahin, and A.K. Abd El-Samed, Port-Said Scientific Engineering Bulletin, Vol.2, No.2, $\mathrm{pp}: 62-77,(1998)$.

[25] Farag; T.M., S.I.,Abdel-Mageed, E-S A., Ibrahim, and A.K. Abd El-Samed, Port-Said Scientific Engineering Bulletin, Vol.2, No.2, pp:78-96,(1998).

[26] Han Y.M., Seol W.S., Lee D.S., Yagodkin V.I., and Jeung I.S., J. Engineering for Gas Turbines and Power, January, vol.123, pp: 33-40, (2001).

[27] Yei-Chin Chao, Yong-Li Chang, Chih-Yung $W u$, and Tsarng-Sheng Cheng, Symposium (International) on Combustion, Vol.28, issue 1, pp:335-342, (2000).

[28] H.Y.Wang, J.K.Bechtold, and C.K.Law, Combustion and Flame, Vol.145, issue 2, pp: 376 389, April (2006).

[29] Chin-Yung Wu, Yei-Chin Chao, Tsamg-Sheng Cheng, Yueh-Heng Li, Kuo-Yuan Lee, and Tony Yuan, Combustion and Flame, Vol.145, issue 3, pp: 481-494, May (2006).

[30] Beèr, J.M., and Chigier, N.A., "Combustion Aerodynamics", Applied Science; London, (1972).

[31] Aly Kamel Abd El-Samed, Port-Said Engineering Research Journal, Vol.6, No.1, pp:100-119, (2002).

[32] Tharwat, M.F., Shaaban, M.M., and AbelMageed, S.I., $7^{\text {th }}$ (Int.) Conference of Mech. Power Engineering, Cairo, Egypt, (1990).

\section{NOMENCLATURE:}

$\alpha \quad$ Angle of the air swirler,

$d_{h} \quad$ Hub diameter of the air swirler,

$d_{s} \quad$ Diameter of the spin chamber,

$r$ certain radial distance,

$\mathbf{R}$ radius of the combustor tube,

$R_{\mathrm{b}} \quad$ Hub radius of the air swirler,

$\mathrm{R}_{\text {out }}$ Outer diameter of the air swirler,

$L$ Length of the combustor tube,

$\mathrm{L}_{\mathrm{s}} \quad$ Depth of the spin chamber,

SN Swirl number,

$\mathrm{x}$ certain axial distance,

$\dot{m}_{c, w} \quad$ mass flow rate of the cooling water

$\mathrm{C}_{\mathrm{pcw}}$ specific heat of the cooling water

$\Delta t$ c.w. temperature difference of the cooling water

\section{Definitions:}

Spin chamber ratio $=\quad$ spin diameter $/$ spin depth Hub diameter ratio $=$ hub diameter / outer diameter 